\title{
How bird droppings can affect the vegetation composition of ombrotrophic bogs
}

\author{
Hilde B.M. Tomassen, Alfons J.P. Smolders, Leon P.M. Lamers, and \\ Jan G.M. Roelofs
}

\begin{abstract}
Ombrotrophic bogs depend on nutrient input from the atmosphere, so bird droppings may be a significant nutrient source. We studied the influx of $\mathrm{N}, \mathrm{P}$, and $\mathrm{K}$ by bird droppings, and the effects of this nutrient influx on the vegetation composition and development of Irish ombrotrophic bogs. Bird droppings significantly increased the influx of $\mathrm{N}, \mathrm{K}$, and particularly P. Concentrations of $\mathrm{N}, \mathrm{P}$, and $\mathrm{K}$ in the peat and vegetation were much higher at sites with bird droppings than at reference sites without bird droppings. Pinus sylvestris L. trees were able to grow much better at the sites with bird droppings, and growth was severely limited by $\mathrm{P}$ and $\mathrm{K}$ at the reference sites. Sites with bird droppings allowed atypical species to grow on ombrotrophic bogs. This change in vegetation composition alters the structure of the ombrotrophic vegetation locally, thereby affecting the atmospheric nutrient input and interception of precipitation.
\end{abstract}

Key words: nitrogen, nutrient limitation, potassium, phosphorus, Pinus sylvestris, soil $\mathrm{CO}_{2}$ evolution, Sphagnum.

Résumé : Les tourbières ombrotrophes dépendent d'apports nutritifs en provenance de l'atmosphère, et conséquemment les déjections d'oiseaux peuvent constituer une source significative de nutriments. Les auteurs ont étudié l'arrivée de N, $\mathrm{P}$ et $\mathrm{K}$ provenant des fientes, ainsi que leurs effets sur la composition de la végétation et le développement de tourbières ombrotrophes, en Irlande. Les fientes augmentent significativement les apports en N, K et particulièrement en P. Les teneurs en N, P et K, dans la végétation et la tourbe, sont beaucoup plus élevées sur les sites recevant des fientes que sur des sites de référence n'en recevant pas. Les Pinus sylvestris L. poussent bien mieux sur les sites avec fientes et leur croissance est limitée par le $\mathrm{P}$ et le $\mathrm{K}$ sur les sites de référence. Les sites recevant des fientes permettent la croissance d'espèces atypiques pour les tourbières ombrotrophes. Cette modification de la composition de la végétation perturbe la structure de la végétation ombrotrophe localement, et conséquemment affecte l'apport en nutriment atmosphérique et l'interception de la précipitation.

Mots clés : azote, nutriment limitant, potassium, phosphore, Pinus sylvestris, évolution du $\mathrm{CO}_{2}$ du sol, Sphagnum.

[Traduit par la Rédaction]

\section{Introduction}

Ombrotrophic bogs are unique ecosystems characterized by vegetation adapted to low nutrient availability. Increased atmospheric nutrient inputs (especially N) can have important effects on the vegetation composition in various natural and seminatural ecosystems (e.g., Bobbink et al. 1998; Bobbink and Lamers 2002) including ombrotrophic bogs (Tomassen et al. 2003; Limpens et al. 2003). As a result of high atmospheric nutrient influx, ombrotrophic bogs have been invaded by more nutrient-demanding species such as Molinia caerulea (L.) Moench. and Betula sp., a

Received 19 October 2004. Published on the NRC Research Press Web site at http://canjbot.nrc.ca on 26 September 2005.

H.B.M. Tomassen, ${ }^{1,2}$ A.J.P. Smolders, ${ }^{2}$ L.P.M. Lamers, and J.G.M. Roelofs. Department of Aquatic Ecology and Environmental Biology, Radboud University Nijmegen, Toernooiveld 1, 6525 ED Nijmegen, the Netherlands.

${ }^{1}$ Corresponding author (e-mail: H.Tomassen@science.ru.nl). ${ }^{2}$ Present address: B-WARE Research Centre, Radbout University, Toernooiveld 1, 6525 ED Nijmegen, the Netherlands. development that has been accompanied by a decline of ombrotrophic species (Barkman 1992; Aaby 1994; Hogg et al. 1995; Risager 1998).

At low $\mathrm{N}$ deposition rates, $\mathrm{N}$ concentrations in the peat water are low as a result of high $\mathrm{N}$ uptake rates by Sphagnum (e.g., Lee and Woodin 1988; Jauhiainen et al. 1998), so vascular plants depend on $\mathrm{N}$ mobilized by mineralization processes in the underlying peat (Malmer 1993; Malmer et al. 1994). At high $\mathrm{N}$ deposition rates, some $\mathrm{N}$ leaches through the Sphagnum layer to the roots of vascular plants (Lee and Woodin 1988; Aerts et al. 1992; Lamers et al. 2000). Increased availability of nutrients in the rhizosphere leads to an increased cover of vascular plants and a reduction in Sphagnum growth because of shading (Hayward and Clymo 1983; Heijmans et al. 2001; Berendse et al. 2001). In addition to this indirect negative effect of $\mathrm{N}$ on Sphagnum, N can have direct toxic effects on Sphagnum mosses (Limpens et al. 2003).

In contrast to Dutch bogs, large-scale invasion of more nutrient-demanding species has not been observed on bogs in the Irish midlands, where total $\mathrm{N}$ deposition rates are relatively low (0.6-0.8 $\mathrm{g} \cdot \mathrm{m}^{-2} \cdot \mathrm{year}^{-1}$; Tomassen et al. 2004). Stands of Betula are, however, common in many parts of Ireland on cut-over and dried-out bogs, or are sometimes associated with flushes or soaks (Cross 1987), which are areas of 
Fig. 1. Betula pubescens (a), Molinia caerulea (b), and Narthecium ossifragum (c) growing in the vicinity of wooden survey posts on which birds have perched and defecated over a period greater than 10 years.

a)

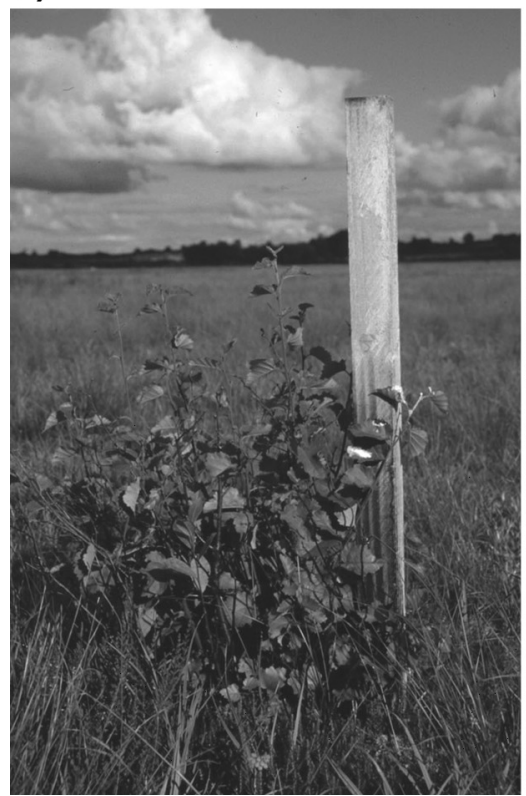

b)

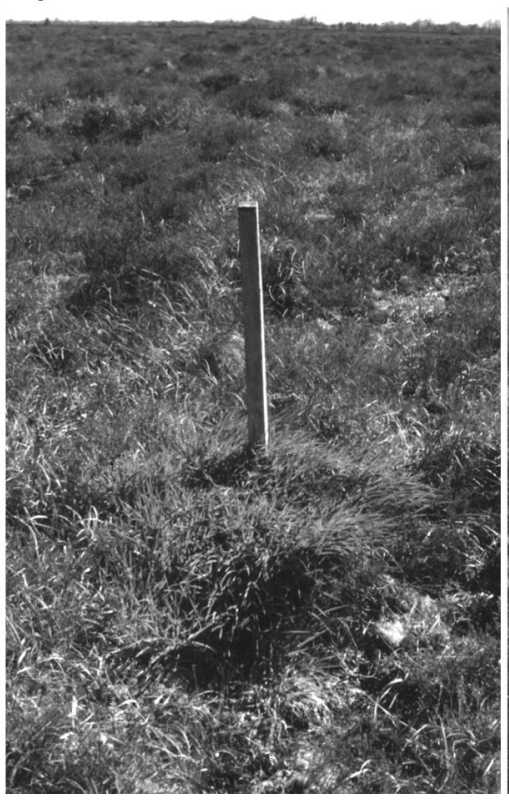

c)

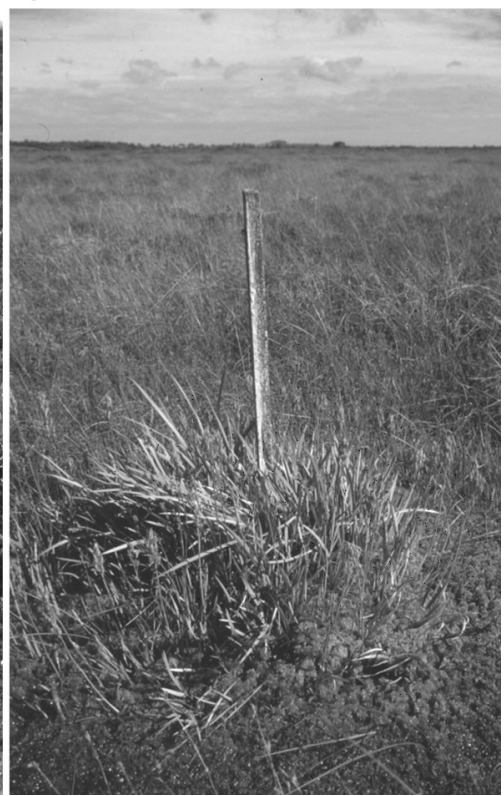

nutrient enrichment. On several Irish bogs, growth of atypical species, such as Molinia caerulea and Betula trees, can be observed in the immediate vicinity of wooden survey posts that were placed there about 10 years ago (Figs. 1a, $1 b$ ). Birds regularly perch on these wooden posts (personal observations) and the increased influx of nutrients from their droppings may be responsible for the observed changes in vegetation composition in the immediate vicinity of the posts. Several studies have reported the effect of large densities of waterfowl on the availability of nutrients ( $\mathrm{N}$ and $\mathrm{P})$ in oligotrophic waters (Leentvaar 1967; Gould and Fletcher 1978; Paffen 1990). Information on the effects of bird droppings on terrestrial vegetation is limited, although there are several studies on the effects of marine bird and mammal faeces on terrestrial ecosystems (e.g., Lindeboom 1979; Cocks et al. 1998, 1999; Fariña et al. 2003). Marine-derived nutrients can be an important nutrient source affecting the development of flora and fauna (Lindeboom 1979). As far as we know there are no studies on the influence of nonmarine bird droppings on terrestrial vegetation.

We hypothesised that the input of nutrients originating from bird droppings might locally affect the vegetation composition and development of ombrotrophic bogs. To test this hypothesis, we measured the influx of major nutrients by bird droppings on Irish bogs. The effects of this influx on the vegetation were determined by comparing the growth of and nutrient concentrations in vegetation exposed to bird droppings with those on nearby unsupplemented reference sites, on three Irish bogs. The effects of bird droppings on the vegetation of ombrotrophic bogs are discussed and put in a larger context.

\section{Materials and methods}

\section{Field sites}

We studied the effects of bird droppings at three ombro- trophic bogs in the midlands of Ireland: Clara bog, Raheenmore bog, and Sharavogue bog. The Irish midlands have a mean annual precipitation of 800-1000 mm (Jordan 1997). The mean annual temperature (1951-1980) is $9.3{ }^{\circ} \mathrm{C}$ and the July and January means are 14.8 and $4.4{ }^{\circ} \mathrm{C}$, respectively. Clara bog (County Offaly; $53^{\circ} 19^{\prime} \mathrm{N} ; 7^{\circ} 37^{\prime} \mathrm{W}$ ) is situated in a depression adjacent to a complex of esker ridges, and its overall depth is in most cases around $10 \mathrm{~m}$ (Warren et al. 2002). Clara bog (665 ha) is $4.2 \mathrm{~km}$ long and $1.2 \mathrm{~km}$ wide and is divided by a road into a western and an eastern part. Raheenmore bog (County Offaly, $53^{\circ} 20^{\prime} \mathrm{N} ; 7^{\circ} 21^{\prime} \mathrm{W}$ ) developed in a depression between a number of low hills, and its peat reaches depths of up to $15 \mathrm{~m}$ (Warren et al. 2002). The actual bog covers approximately 160 ha. In 1990-1991, wooden posts were placed on both Clara bog and Raheenmore bog for hydrological research (Van der Schaaf 1999). The vegetation near these posts is dominated by atypical species such as Molinia caerulea, Betula pubescens Ehrh., Pinus sylvestris L., Juncus effusus L., and Agrostis canina L. (Figs. 1a, 1b). Among the bird species that use the survey posts are the Hooded crow (Corvus corone cornix), Common krestel (Falco Tinnunculus), and the Stonechat (Saxicola torquata). Sharavogue bog (County Offaly, $\left.53^{\circ} 02^{\prime} \mathrm{N} ; 7^{\circ} 54^{\prime} \mathrm{W}\right)$ is characterized by several small Pinus sylvestris stands on the bog (223 ha). The understorey vegetation of these stands includes species such as Molinia caerulea and J. effusus, which indicate more eutrophic conditions.

\section{Vegetation}

At Clara bog, five sites affected by bird droppings were selected in the vicinity of survey posts (area of $1 \mathrm{~m}^{2}$ ). The vegetation composition in the vicinity of all the posts showed distinct changes and five survey posts were selected randomly. Nearby these posts, five reference sites (area of $1 \mathrm{~m}^{2}$ ) were selected based on vegetation composition. At a 
Table 1. Vegetation cover (\%) at a reference site $2 \mathrm{~m}$ from the wooden survey posts and in the immediate vicinity of the posts at Clara bog $(n=5)$.

\begin{tabular}{|c|c|c|c|c|c|c|c|c|c|c|}
\hline & \multicolumn{5}{|c|}{ Reference } & \multicolumn{5}{|c|}{ Post } \\
\hline & 1 & 2 & 3 & 4 & 5 & 1 & 2 & 3 & 4 & 5 \\
\hline Cladonia portentosa (Dufour) Coem. & + & & + & & 20 & & & & & \\
\hline Drosera rotundifolia $\mathrm{L}$. & \# & & 10 & 5 & \# & & & & & \\
\hline Menyanthes trifoliata $\mathrm{L}$. & + & & & & & & & & & \\
\hline Rhynchospora alba (L.) Vahl & + & 5 & 5 & & + & & & & & \\
\hline Calluna vulgaris (L.) Hull & 5 & 10 & 5 & 35 & + & & 10 & & + & \\
\hline Carex echinata Murray & 5 & & & & & $\#$ & & & & \\
\hline Carex panacea $\mathrm{L}$. & & & & & 0 & & & & & 10 \\
\hline Erica tetralix $\mathrm{L}$. & 5 & 20 & 5 & 5 & 5 & + & & & 5 & \\
\hline Eriophorum angustifolium Honck. & \# & \# & \# & \# & & \# & & + & & + \\
\hline Sphagnum magellanicum Brid. & 25 & 15 & 30 & 10 & + & & \# & & & \\
\hline Sphagnum papillosum Lindb. & 35 & \# & + & & 10 & 5 & & & & \\
\hline Sphagnum rubellum Wils. & 10 & & 40 & 45 & 60 & & & & & 5 \\
\hline Agrostis canina $\mathrm{L}$. & & & & & & $\#$ & & & & 35 \\
\hline $\begin{array}{l}\text { Cerastium fontanum Baumg. subsp. vulgare (Hartm.) } \\
\text { Greuter \& Burdet }\end{array}$ & & & & & & & & & 10 & + \\
\hline Comarum palustre $\mathrm{L}$. & & & & & & & + & & & \\
\hline Epilobium hirsutum L. & & & & & & & + & & & \\
\hline Holcus lanatus L. & & & & & & & & 85 & & \\
\hline Hydrocotyle vulgaris $\mathrm{L}$. & & & & & & & + & & & \\
\hline Molinia caerulea (L.) Moench & & & & & & 90 & 80 & & & \\
\hline
\end{tabular}

Note: +, several individuals; \#, large number of individuals but no significant cover.

distance of approximately $2 \mathrm{~m}$ from the survey posts, there were no visible changes in vegetation composition present. The vegetation was described in terms of the percentage cover of vascular plants, bryophytes, and lichens. In the case of species with an insignificant amount of cover $(<5 \%)$, the number of individuals was estimated $(+$, several individuals; \#, large number of individuals).

\section{Input of nutrients by bird droppings}

Input of nutrients by bird droppings was measured around three wooden survey posts on Clara bog east by collecting precipitation and bird droppings using a polyethylene container $(10 \mathrm{~L})$ connected to a circular funnel $(22 \mathrm{~cm}$ diameter). Background input of nutrients $(n=3)$ was measured by collecting bulk precipitation using a black polyethylene bottle $(2 \mathrm{~L})$ connected to a funnel $(9.75 \mathrm{~cm}$ diameter $)$ according to Tomassen et al. (2004). The collectors were dug in the peat and contained $2 \mathrm{~mL}$ of a $200 \mathrm{mg} \cdot \mathrm{L}^{-1} \mathrm{HgCl}_{2}$ solution to inhibit microbial activity. Between September 2000 and September 2001, rainwater including bird droppings and rainwater were collected eight times (November 2000, February, March, April, May, June, July, and September 2001) and the volume was measured in the field. Part of the bird dropping samples was filtered through a Whatman GF/C filter (pore size of $1.2 \mu \mathrm{m}$ ). This method allowed us to measure only the soluble part of the nutrients from the bird droppings and will underestimate the total nutrient input by bird droppings. Samples were stored at $-20{ }^{\circ} \mathrm{C}$ until further analysis.

\section{Effect of bird droppings on the nutrient concentrations in the vegetation}

On Clara bog, nutrient concentrations in the top layer of the peat $(0-10 \mathrm{~cm})$ were measured in the immediate vicinity of the survey posts $(n=5)$ and at reference sites $(2 \mathrm{~m}$ from the posts; $n=5$ ). The peat was characterized as poorly 
Table 2. Mean \pm SE $(n=3)$ influx from precipitation and precipitation including bird droppings (September 2000 - September 2001) of $\mathrm{N}\left(\mathrm{NH}_{4}^{+}\right.$and $\left.\mathrm{NO}_{3}^{-}\right), \mathrm{P}$, and $\mathrm{K}$ at Clara bog.

\begin{tabular}{lllll}
\hline & $\mathrm{NH}_{4}{ }^{+}-\mathrm{N}\left(\mathrm{g} \cdot \mathrm{m}^{-2} \cdot \mathrm{year}^{-1}\right)$ & $\mathrm{NO}_{3}{ }^{-}-\mathrm{N}\left(\mathrm{g} \cdot \mathrm{m}^{-2} \cdot \mathrm{year}^{-1}\right)$ & $\mathrm{P}\left(\mathrm{g} \cdot \mathrm{m}^{-2} \cdot \mathrm{year}^{-1}\right)$ & $\mathrm{K}\left(\mathrm{g} \cdot \mathrm{m}^{-2} \cdot \mathrm{year}{ }^{-1}\right)$ \\
\hline Influx from precipitation & $0.3 \pm 0.1$ & $0.14 \pm 0.00$ & $0.02 \pm 0.00$ & $0.2 \pm 0.1$ \\
Influx from bird droppings & $18.4 \pm 2.3 * * *$ & $0.04 \pm 0.00 * * *$ & $3.52 \pm 0.76^{* * *}$ & $6.0 \pm 1.6^{* * *}$ \\
\hline
\end{tabular}

Note: ***, statistical significance at $P \leq 0.001$ ( $t$ test).

Table 3. $\mathrm{N}, \mathrm{P}$, and $\mathrm{K}$ concentrations on a dry mass basis, $\mathrm{C}: \mathrm{N}$ and $\mathrm{C}: \mathrm{P}$ ratios, and $\mathrm{CO}_{2}$ production rate (mean \pm 1 SE) of superficial peat $(0-10 \mathrm{~cm})$ at a reference site $2 \mathrm{~m}$ from the wooden survey posts and in the immediate vicinity of posts at Clara bog $(n=5)$.

\begin{tabular}{lclclll}
\hline & $\mathrm{N}\left(\mu \mathrm{mol} \cdot \mathrm{g}^{-1}\right)$ & $\mathrm{P}\left(\mu \mathrm{mol} \cdot \mathrm{g}^{-1}\right)$ & $\mathrm{K}\left(\mu \mathrm{mol} \cdot \mathrm{g}^{-1}\right)$ & $\mathrm{C}: \mathrm{N}$ ratio $\left(\mathrm{g} \cdot \mathrm{g}^{-1}\right)$ & $\mathrm{C}: \mathrm{P}$ ratio $\left(\mathrm{g} \cdot \mathrm{g}^{-1}\right)$ & $\begin{array}{c}\mathrm{CO} \\
\mathrm{rate}\left(\mu \mathrm{mol} \cdot \mathrm{g}^{-1} \cdot \mathrm{d}^{-1}\right)\end{array}$ \\
\hline Reference & $879 \pm 78$ & $13 \pm 2$ & $8.3 \pm 0.8$ & $40 \pm 4$ & $1246 \pm 119$ & $11.7 \pm 5.9$ \\
Post & $1832 \pm 274 * *$ & $57 \pm 16^{* * *}$ & $28.6 \pm 2.8^{* * *}$ & $21 \pm 3 * *$ & $350 \pm 66^{* * *}$ & $25.3 \pm 12.7 *$ \\
\hline
\end{tabular}

Note: *, statistical significance at $P \leq 0.05$; **, statistical significance at $P \leq 0.01$; ***, statistical significance at $P \leq 0.001$ ( $t$ test).

Table 4. Capitulum N, P, and $\mathrm{K}$ concentrations on a dry mass basis, and N:P, N:K, and P:K ratios (mean \pm 1 SE) in Sphagnum from reference sites $(n=6)$ and sites affected by bird droppings $(n=11)$ at three Irish bogs (Clara bog, Sharavogue bog, and Raheenmore bog).

\begin{tabular}{lccclll}
\hline & $\mathrm{N}\left(\mu \mathrm{mol} \cdot \mathrm{g}^{-1}\right)$ & $\mathrm{P}\left(\mu \mathrm{mol} \cdot \mathrm{g}^{-1}\right)$ & $\mathrm{K}\left(\mu \mathrm{mol} \cdot \mathrm{g}^{-1}\right)$ & $\mathrm{N}: \mathrm{P}$ ratio $\left(\mathrm{g} \cdot \mathrm{g}^{-1}\right)$ & $\mathrm{N}: \mathrm{K}$ ratio $\left(\mathrm{g} \cdot \mathrm{g}^{-1}\right)$ & $\mathrm{P}: \mathrm{K} \mathrm{ratio}\left(\mathrm{g} \cdot \mathrm{g}^{-1}\right)$ \\
\hline Reference & $412 \pm 28$ & $9 \pm 1$ & $78 \pm 4$ & $22 \pm 2$ & $1.9 \pm 0.1$ & $0.09 \pm 0.01$ \\
Post & $1086 \pm 58 * * *$ & $49 \pm 4 * * *$ & $128 \pm 7 * * *$ & $11 \pm 1 * * *$ & $3.2 \pm 0.3 \mathrm{~ns}$ & $0.31 \pm 0.03 * * *$ \\
\hline
\end{tabular}

Note: ns, not significant $(P>0.05) ; * *$, statistical significance at $P \leq 0.001(t$ test $)$.

Table 5. Length of longest leaf, $\mathrm{N}, \mathrm{P}$, and $\mathrm{K}$ concentrations on a dry mass basis, and $\mathrm{N}: \mathrm{P}, \mathrm{N}: \mathrm{K}$ and $\mathrm{P}: \mathrm{K}$ ratios (mean \pm 1 SE) in Narthecium ossifragum from a reference site $2 \mathrm{~m}$ from the posts $(n=2)$ and the immediate vicinity of posts $(n=3)$ at Clara bog.

\begin{tabular}{|c|c|c|c|c|c|c|c|}
\hline & $\begin{array}{l}\text { Length of longest } \\
\text { leaf }(\mathrm{mm})\end{array}$ & $\mathrm{N}\left(\mu \mathrm{mol} \cdot \mathrm{g}^{-1}\right)$ & $\mathrm{P}\left(\mu \mathrm{mol} \cdot \mathrm{g}^{-1}\right)$ & $\mathrm{K}\left(\mu \mathrm{mol} \cdot \mathrm{g}^{-1}\right)$ & $\begin{array}{l}\mathrm{N}: \mathrm{P} \text { ratio } \\
\left(\mathrm{g} \cdot \mathrm{g}^{-1}\right)\end{array}$ & $\begin{array}{l}\mathrm{N}: \mathrm{K} \text { ratio } \\
\left(\mathrm{g} \cdot \mathrm{g}^{-1}\right)\end{array}$ & $\begin{array}{l}\mathrm{P}: \mathrm{K} \text { ratio } \\
\left(\mathrm{g} \cdot \mathrm{g}^{-1}\right)\end{array}$ \\
\hline Reference & $86 \pm 5$ & $1089 \pm 43$ & $12 \pm 1$ & $326 \pm 25$ & $41 \pm 4$ & $1.2 \pm 0.0$ & $0.03 \pm 0.00$ \\
\hline
\end{tabular}

Note: ns, not significant; *, statistical significance at $P \leq 0.05$; **, statistical significance at $P \leq 0.01$; ***, statistical significance at $P \leq 0.001$ ( $t$ test).

humified Sphagnum peat. The peat was stored in airtight plastic bags at $4{ }^{\circ} \mathrm{C}$ until chemical analysis. Uptake of birdderived nutrients by Sphagnum mosses was determined by comparing nutrient concentrations in the capitula $(0-2 \mathrm{~cm})$ of Sphagnum magellanicum Brid. or Sphagnum papillosum Lindb. at sites with bird droppings $(n=11)$ and at reference sites without bird droppings $(n=6)$. In addition to Sphagnum from Clara bog (posts), we also analysed Sphagnum plants from Raheenmore bog (around posts) and Sharavogue bog (underneath Pinus sylvestris trees). For Narthecium ossifragum L. the length of the longest leaf and foliar nutrient concentrations ( 15 plants per location) were measured in the immediate vicinity of wooden posts $(n=3)$ and at reference sites ( $2 \mathrm{~m}$ from the posts; $n=2)$ at Clara bog.

Sharavogue bog is characterized by several small groups of Pinus sylvestris trees with an understorey dominated by Calluna vulgaris (L.) Hull, Molinia caerulea, B. pubescens, Vaccinium myrtillus L., and J. effusus. The larger trees supported nests of the Hooded crow and bird droppings were obvious. All the small Pinus trees were established in 1989, which was an extremely dry year (Mills 2000). During this drought there was a fire that probably destroyed all Pinus seedlings. The young Pinus trees at a larger distance from the "mother" tree were much smaller, though they all became established directly after the fire (1989). To determine the effects of bird droppings on the growth of these trees, tree height and lifespan of the needles (number of year classes present) were determined in three transects going out from a randomly chosen "mother" tree. On Clara bog east, the effects of bird droppings on Pinus sylvestris were examined experimentally by planting small Pinus trees near wooden posts $(n=4)$ as well as at a distance of $5 \mathrm{~m}$ from these posts $(n=4)$. Trees were planted in September 2000. The Pinus trees (height of $52 \pm 5 \mathrm{~cm}$ ) were collected in a nearby cut-away. In July 2002, the growth of the trees was determined by measuring the increase in height, the length of the current year's shoot and needles, and the lifespan of the needles. Needle samples were taken for analysis of major nutrient concentrations.

\section{Chemical analysis}

To analyse nutrient concentrations in plant tissue and peat, dried samples $\left(48 \mathrm{~h}\right.$ at $70{ }^{\circ} \mathrm{C}$ ) were ground in liquid nitrogen. Nitrogen and carbon concentrations were measured in dried samples with a CNS analyser (type NA1500; Carlo Erba Instruments, Milan, Italy). Potassium and phosphorus 
Fig. 2. Height $(a)$ and lifespan of needles $(b)$ of Pinus sylvestris trees measured in three transects (A-C) starting from the "mother" tree $(0 \mathrm{~m})$ at Sharavogue bog, September 2000. All trees were 11 years old. Linear regression yields for height: $P_{A}=0.01, P_{B}=$ 0.003 , and $P_{C}=0.02$; linear regression yields for lifespan of needles: $P_{A}=0.003, P_{B}=0.03$, and $P_{C}=0.003$.
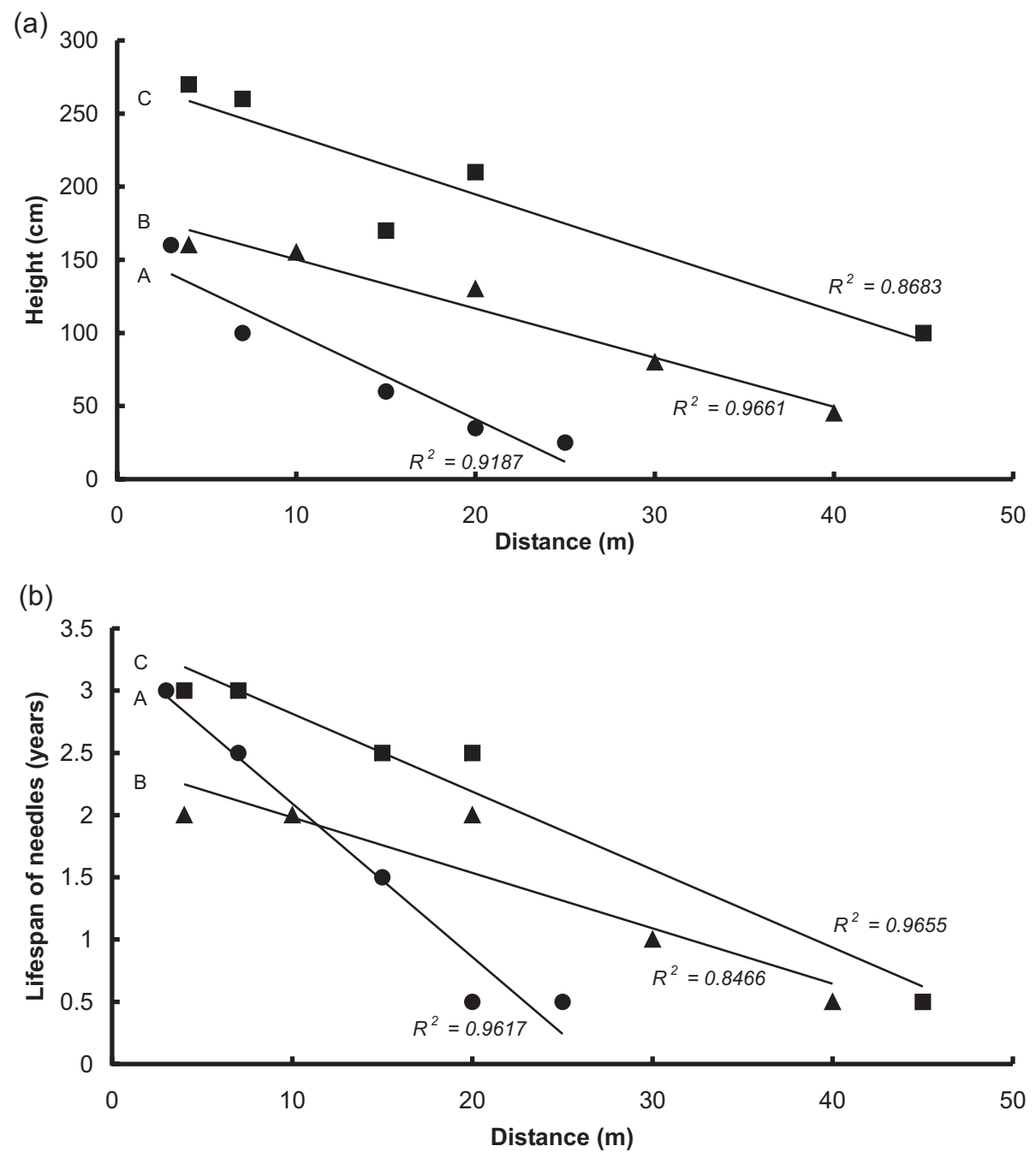

concentrations were determined by digesting $200 \mathrm{mg}$ of dried material in sealed Teflon vessels in a Milestone microwave oven (mls 1200 Mega, Sorisole, Italy) after addition of

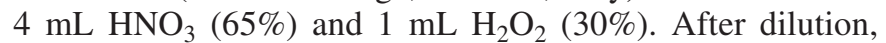
the digests were kept at $4{ }^{\circ} \mathrm{C}$ until analysis.

Nitrate and ammonium concentrations of water samples and digests were measured colorimetrically with a Traacs 800+ auto-analyzer, using hydrazine sulphate (Technicon 1969) and salicylate (Grasshoff and Johannsen 1977), respectively. Potassium concentrations were measured by flame photometry (FLM3 Flame Photometer, Radiometer, Copenhagen, Denmark). Phosphorus was determined by inductively coupled plasma emission spectrophotometry (Spectroflame, Spectro Analytical Instruments, Kleve, Germany).

Potential $\mathrm{CO}_{2}$ production rates of the collected peat were measured by incubating $50 \mathrm{~g}$ of fresh peat in air-filled 250$\mathrm{mL}$ infusion flasks, sealed with airtight stoppers. Duplicate incubations were made. The flasks were kept in the dark at $20{ }^{\circ} \mathrm{C}$, and over a period of 4 weeks $\mathrm{CO}_{2}$ concentrations in the headspace were measured weekly. $\mathrm{CO}_{2}$ concentrations were measured using an infrared carbon analyzer (model
PIR-2000, Horiba Instruments, Irvine, California). $\mathrm{CO}_{2}$ production rates were calculated by linear regression of the measurements and expressed on a dry mass basis.

\section{Statistical analysis}

Prior to statistical analysis, data were log-transformed to make the variance less dependent on the means and so that the data were approximately Gaussian. All statistical analyses were carried out using SPSS ${ }^{\circledR}$ for Windows software package (version 10.0.7; SPSS Inc., Chicago, Illinois). Differences between sites with bird droppings and reference sites without bird droppings were tested with an independent samples $t$ test. Correlations between height and lifespan of the needles of the small Pinus sylvestris trees and the distance from the "mother" tree were analysed with a Pearson correlation test and described by a linear regression analysis. For clarity of presentation, the means and standard errors (SE) presented in the tables are for the untransformed data.

\section{Results}

The vegetation around the wooden posts on Clara bog was 
Table 6. Growth variables, nutrient concentrations on a dry mass basis, and ratios in current year's needles (mean \pm 1 SE) of Pinus sylvestris in July 2002, 2 years after transplantation (September 2000) to reference sites $2 \mathrm{~m}$ from the survey posts and to the immediate vicinity of survey posts, at Clara bog $(n=4)$.

\begin{tabular}{lll}
\hline Variable & Reference & Post \\
\hline Length of current year's shoot $(\mathrm{cm})$ & $4.0 \pm 0.5$ & $28.5 \pm 3.5^{* * *}$ \\
Total height $(\mathrm{cm})$ & $59 \pm 10$ & $86 \pm 3^{*}$ \\
Length of needles $(\mathrm{cm})$ & $3.0 \pm 0.5$ & $5.9 \pm 0.4^{* *}$ \\
Lifespan of needles (years) & $1.6 \pm 0.1$ & $2.8 \pm 0.1^{* * *}$ \\
Increase in height between 2000 and 2002 $(\%)$ & $13 \pm 3$ & $80 \pm 21^{*}$ \\
Change of length of current year's shoot between 2000 and $2002(\%)$ & $-47 \pm 15$ & $201 \pm 64^{*}$ \\
$\mathrm{~N}\left(\mu \mathrm{mol} \cdot \mathrm{g}^{-1}\right)$ & $1104 \pm 172$ & $811 \pm 59 \mathrm{~ns}$ \\
$\mathrm{P}\left(\mu \mathrm{mol} \cdot \mathrm{g}^{-1}\right)$ & $17 \pm 3$ & $37 \pm 8^{*}$ \\
$\mathrm{~K}\left(\mu \mathrm{mol} \cdot \mathrm{g}^{-1}\right)$ & $84 \pm 25$ & $65 \pm 8 \mathrm{~ns}$ \\
$\mathrm{~N}: \mathrm{P}$ ratio $\left(\mathrm{g} \cdot \mathrm{g}^{-1}\right)$ & $33 \pm 8$ & $10 \pm 1^{*}$ \\
$\mathrm{~N}: \mathrm{K}$ ratio $\left(\mathrm{g} \cdot \mathrm{g}^{-1}\right)$ & $5.8 \pm 1.5$ & $4.7 \pm 0.8 \mathrm{~ns}$ \\
$\mathrm{P}: \mathrm{K}$ ratio $\left(\mathrm{g} \cdot \mathrm{g}^{-1}\right)$ & $0.2 \pm 0.1$ & $0.5 \pm 0.2 \mathrm{~ns}$ \\
\hline
\end{tabular}

Note: ns, not significant; *, statistical significance at $P \leq 0.05$;**, statistical significance at $P \leq 0.01$; ***, statistical significance at $P \leq 0.001$ ( $t$ test $)$

Fig. 3. Pinus sylvestris trees growing at a reference site $2 \mathrm{~m}$ from a wooden survey post $(a)$ and in the vicinity of a wooden survey post $(b)$ at Clara bog east, 2 years after transplantation.

a)

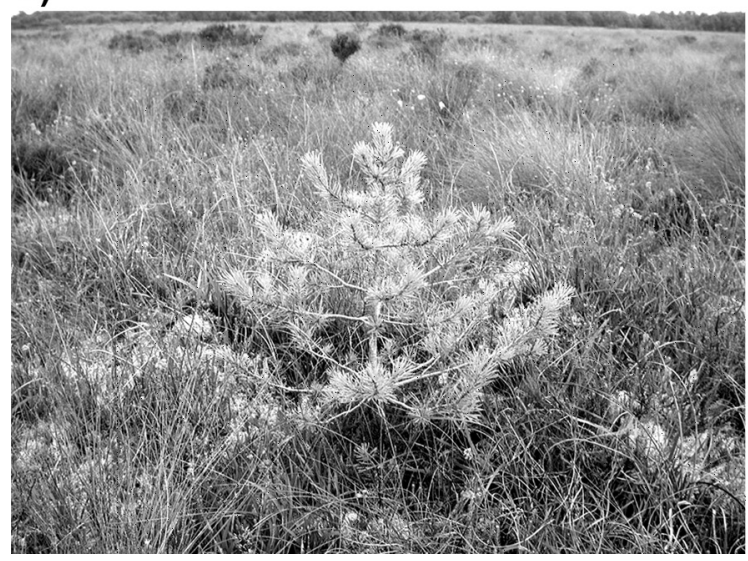

frequently dominated by atypical species, including Molinia caerulea, Agrostis canina, Epilobium hirsutum L., Rubus fruticosus L., Holcus lanatus L., Poa annua L., and Trifolium repens L. (Table 1), all of which were absent from the reference sites. Some typical bog species, such as Sphagnum mosses, had lower amounts of cover; others such as Drosera rotundifolia (L.) Vahl and Rhynchospora alba L. were absent from the areas around the posts (Table 1).

Table 2 shows that the influx of $\mathrm{N}, \mathrm{P}$, and $\mathrm{K}$ in bird droppings was tens or hundreds of times greater than that in precipitation. This difference was reflected in the peat (Table 3), although the concentration at the site with bird droppings was only a fewfold greater than at the reference site. At sites with bird droppings, peat $\mathrm{C}: \mathrm{N}$ and $\mathrm{C}: \mathrm{P}$ ratios were significantly lower, and the potential $\mathrm{CO}_{2}$ production rate was increased (Table 3 ). Increased input of $\mathrm{N}, \mathrm{P}$, and $\mathrm{K}$ by bird droppings significantly affected nutrient concentrations in Sphagnum (Table 4). The N:P ratio in Sphagnum was significantly lower, and the $\mathrm{P}: \mathrm{K}$ ratio significantly higher at the site with bird droppings than at the reference site. Narthecium ossifragum (L.) Huds. plants were significantly taller and $\mathrm{P}$ concentrations, and $\mathrm{N}: \mathrm{K}$ and $\mathrm{P}: \mathrm{K}$ ratios b)

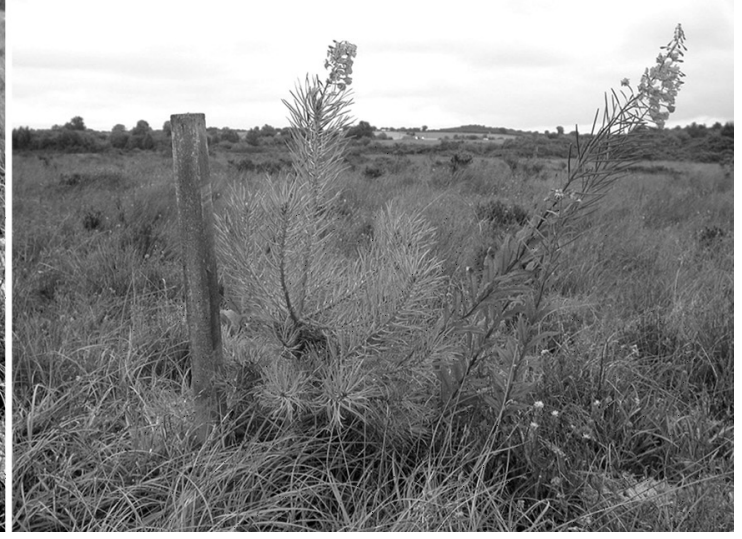

were significantly greater at the site with bird droppings than at the reference sites (Table 5 and Fig. 1c). Foliar $\mathrm{N}$ concentrations were unaffected, but $\mathrm{K}$ concentrations and $\mathrm{N}: \mathrm{P}$ ratios were significantly lower at the site with bird droppings.

At Sharavogue bog, the small Pinus sylvestris trees of similar age were significantly taller closer to the "mother" tree than at greater distances (Fig. 2a). The lifespan of the needles was significantly longer close to the "mother" tree (Fig. 2b). Overall, the trees were more vigorous closer to the "mother" tree. On Clara bog, transplantation of small Pinus sylvestris trees to the immediate vicinity of the wooden posts significantly stimulated the growth of these trees compared with trees transplanted to reference sites (Table 6). The trees growing around the posts were more vigorous (Fig. 3) and the length of the current year's shoots (of the 2002 growing season) was significantly greater, while the needles had a longer lifespan (Table 6). The total height increase of the trees between September 2000 and July 2002 was $13 \%$ at the reference sites, compared with $80 \%$ around the posts. The length of the current year's shoots in 2002 was $47 \%$ smaller than that for 2000 at the reference sites and 
Fig. 4. Change in total height (mean \pm 1 SE; $n=4$ ) of Pinus sylvestris trees between September 2000 and June 2004, 4 years after transplantation to reference sites $2 \mathrm{~m}$ from survey posts and to the immediate vicinity of the posts at Clara bog. Results for General Linear Model (GLM) for repeated measures are as follows: $P<0.01$ for bird-droppings effect, $P<0.001$ for time effect, and $P<0.01$ for bird dropping $\times$ time interaction.

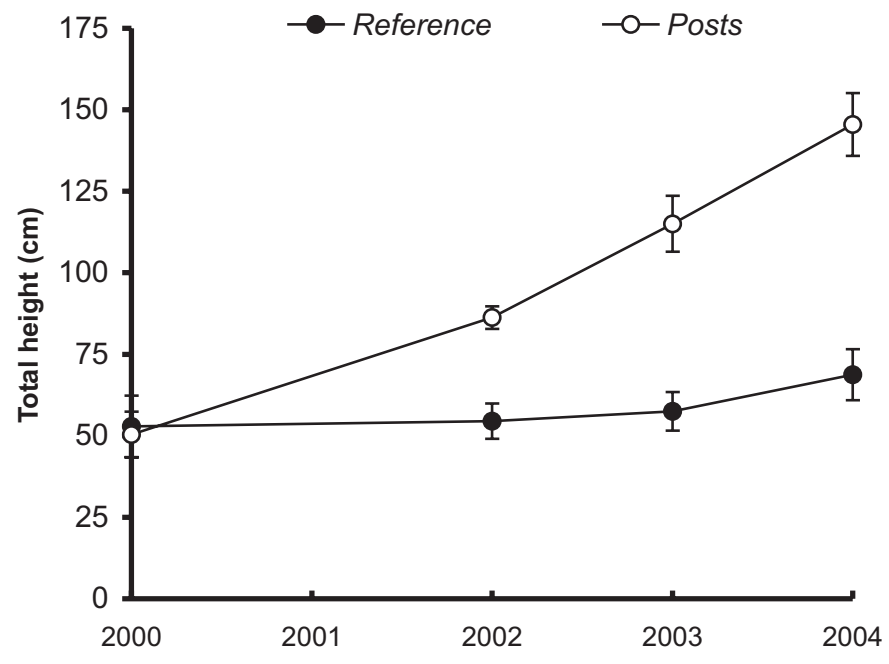

$201 \%$ larger than that for 2000 next to the wooden posts (Table 6). P concentrations measured in the current year's needles (2002) of the Pinus trees were significantly increased in the immediate vicinity of the posts, whereas $\mathrm{N}$ and $\mathrm{K}$ concentrations remained unaffected (Table 6). N:P ratios in the needles were significantly greater at the reference sites.

\section{Discussion}

\section{Bird droppings and vegetation composition}

Ombrotrophic bogs are oligotrophic ecosystems that are very sensitive to changes in nutrient availability (Aerts et al. 1992; Bobbink et al. 1998). The total $\mathrm{N}$ deposition rates in the Irish midlands are below the critical $\mathrm{N}$ load for ombrotrophic bogs (0.5-1.0 $\mathrm{g} \cdot \mathrm{m}^{-2} \cdot \mathrm{year}^{-1}$; Bobbink and Roelofs 1995; Risager 1998; Tomassen et al. 2003), and invasion of atypical species such as Molinia caerulea and $B$. pubescens has not been observed. By contrast, atypical species were able to grow in the immediate vicinity of wooden survey posts (Fig. 1), whereas characteristic species decreased in amount of cover or even disappeared. The colonizing species include eutrophic species such as Molinia caerulea, Rubus fruticosus, Holcus lanatus, and Poa annua. Although the survey posts will influence the air flow regime, thereby affecting the evapotranspiration of plants in the immediate vicinity of the posts, these effects will be trivial compared with the effect of the extremely high input of nutrients by bird droppings (Table 2). The input of nutrients leaching from the wooden posts will be negligible since this is very likely to be a slow process. The development of this fast-growing and dense vegetation limits light availability for Sphagnum and lichens (Hayward and Clymo 1983; Heijmans et al. 2001; Limpens et al. 2003). The disappearance of Sphagnum mosses and lichens from the birddropping sites will lead to higher nutrient concentrations in the rhizosphere and stimulate the colonization by atypical species (Lamers et al. 2000; Tomassen et al. 2003; Limpens et al. 2003). At low nutrient availability, Sphagnum immobilizes most of the nutrients, leading to relatively low nutrient availability in the rhizosphere of vascular plants (Lamers et al. 2000; Berendse et al. 2001). Increased nutrient input will ultimately lead to higher nutrient availability for (more nutrient-demanding) vascular plants as the Sphagnum filter becomes saturated (Lamers et al. 2000). In addition, high nutrient concentrations can be toxic for Sphagnum and lichens and retard the growth of these species (Limpens et al. 2003; Tomassen et al. 2004). Summarizing, the lack of Sphagnum cover in the vicinity of the posts because of poisoning by bird droppings and competition with vascular plants at elevated nutrient levels, is an important mechanism that has paved the way for atypical plant species. Van der Wal et al. (2004) found that faeces of reindeer (Rangifer tarandus platyrhynchus) had cascading effects on tundra ecosystems by promoting grasses while suppressing mosses.

\section{Bird droppings and nutrient limitation in ombrotrophic vegetation}

We measured the input of nutrients in the vicinity of the survey posts by collecting bird droppings. Only the input of soluble inorganic $\mathrm{N}$ was measured, but even then bird droppings increased the total inorganic $\mathrm{N}$ input rate to $18.5 \mathrm{~g} \cdot \mathrm{m}^{-2} \cdot$ year $^{-1}$. The actual input of $\mathrm{N}$ will be much higher since bird droppings contain large amounts of organic $\mathrm{N}$ compounds (e.g., urea) and some of the $\mathrm{N}$ could have been volatilized. The input rate of inorganic $\mathrm{N}$ far exceeds the critical $\mathrm{N}$ load for ombrotrophic bogs: $0.5-1.0 \mathrm{~g} \mathrm{~N} \cdot \mathrm{m}^{-2} \cdot$ year $^{-1}$ (Bobbink and Roelofs 1995). Above this critical $N$ load, changes in the vegetation composition can be expected, as has been found in the Netherlands, where total $\mathrm{N}$ deposition rates are extremely high (approx. $4 \mathrm{~g} \mathrm{~N} \cdot \mathrm{m}^{-2} \cdot$ year $^{-1}$; e.g., Tomassen et al. 2003). The sites with bird droppings were characterized by increased availability of all major nutrients, and the top peat layer had significantly higher $\mathrm{N}, \mathrm{P}$, and $\mathrm{K}$ concentrations (Table 3). Cocks et al. (1999) also found that soils near Snow petrel nests contained high levels of $\mathrm{N}$ and $\mathrm{P}$ ( $\mathrm{K}$ was not measured) and that the effects of the bird droppings were no longer noticeable at a distance of $2 \mathrm{~m}$. We also found that the influence of the bird droppings was very local given the large differences in peat nutrient concentrations over a limited distance of only $2 \mathrm{~m}$ (Table 2 ).

Nutrient availability usually limits the activity of decomposing organisms and it seems likely that decomposition processes are stimulated when $\mathrm{C}: \mathrm{N}, \mathrm{C}: \mathrm{P}$, or $\mathrm{C}: \mathrm{K}$ ratios are low and N, P, or K concentrations are high (e.g., Swift et al. 1979; Updegraff et al. 1995; Smolders et al. 2002). In our study, the potential $\mathrm{CO}_{2}$ production rate of the peat was greater around the posts, where nutrient concentrations were significantly increased (Table 3 ). The effects of changes in peat quality on decomposition and nutrient cycling result in stimulated mobilization and availability of nutrients for the vegetation. The NPK fertilization by bird droppings had a remarkable effect on the vegetation near the posts, within a relatively short period (Table 1). Maksimova and Yudina (1999) showed that even much lower NPK fertilization rates $\left(0.5,1\right.$, and $0.75 \mathrm{~g} \cdot \mathrm{m}^{-2} \cdot$ year $^{-1}$, respectively), applied for 6 years in a Sedge-Sphagnum bog, led to rapid changes in the vege- 
Fig. 5. Simplified scheme of the effects of bird droppings on ombrotrophic bog vegetation.

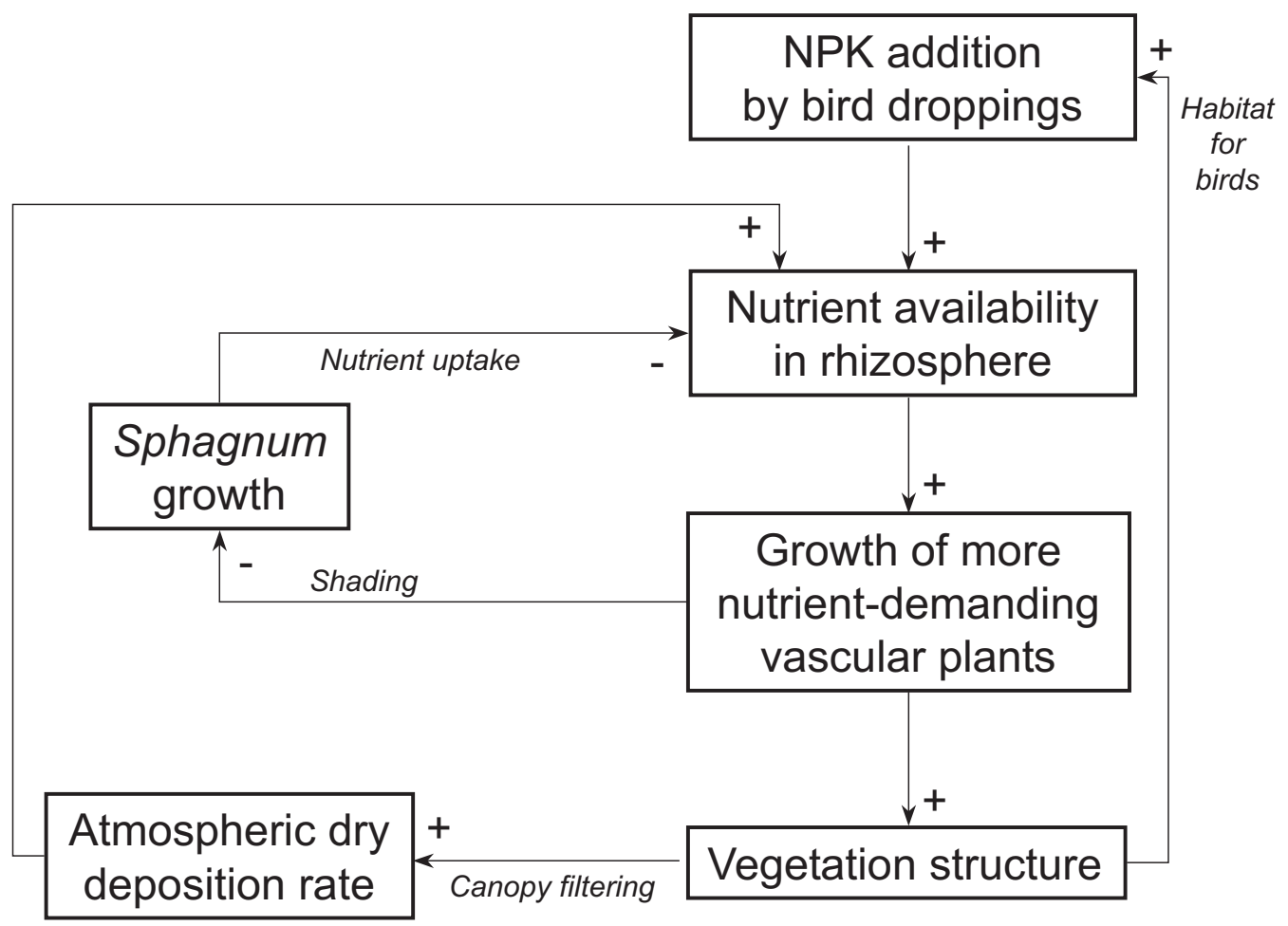

tation composition, even 15 years after their application ceased. We need to address that they supplied a relative higher amount of $\mathrm{P}$ when compared with the NPK composition of bird droppings (Table 2).

The increased input of nutrients around the posts was also reflected in much higher $\mathrm{N}, \mathrm{P}$, and $\mathrm{K}$ concentrations in the capitula of Sphagnum mosses (Table 4). A stable isotope study in Antarctica showed that bird droppings were a major source of $\mathrm{N}$ for the vegetation (Cocks et al. 1998). The tissue N:P ratio exceeded 16, indicating that growth of Sphagnum at the reference sites was limited by $\mathrm{P}$ and growth at the sites with bird droppings was limited by $\mathrm{N}$ ( $\mathrm{N}: \mathrm{P}$ ratio $<14$; Koerselman and Meuleman 1996). Limpens et al. (2004) also found that growth of Sphagnum in Ireland (Clara bog) is limited by $\mathrm{P}$. Although $\mathrm{N}$ deposition rates in Ireland are below the critical N load for ombrotrophic bogs, Sphagnum productivity is limited by $\mathrm{P}$. If, however, $\mathrm{K}$ is also taken into account, Sphagnum growth at the reference sites was colimited by $\mathrm{P}$ and $\mathrm{K}$, while growth at the sites with bird droppings was limited by $\mathrm{K}$ alone (a tissue $\mathrm{N}: \mathrm{K}$ ratio above 1.4 indicates $\mathrm{K}$ limitation; Hoosbeek et al. 2002). The P:K ratio was significantly higher at the bird dropping sites, indicating the relative limitation of $\mathrm{K}$ compared with $\mathrm{P}$. According to Hoosbeek et al. (2002), Sphagnum growth in bogs of northwestern Europe is often limited (or co-limited) by $\mathrm{K}$.

Although the vegetation around the posts was frequently dominated by atypical species, $N$. ossifragum, which is a characteristic plant for bogs, was also able to profit from the increased input of nutrients by increasing its length (Fig. $1 c$ and Table 5). The growth rate of $N$. ossifragum on mires in the United Kingdom has been found to be determined by the supply and uptake of phosphate and calcium (Summerfield and Rieley 1975). Based on the $\mathrm{N}: \mathrm{P}$ ratio we measured, growth of $N$. ossifragum was limited by $\mathrm{P}$ at both the refer- ence and bird dropping sites (Koerselman and Meuleman 1996). A fertilization experiment in southern Sweden showed also that $\mathrm{P}$ is a growth-limiting nutrient for $N$. ossifragum (Malmer et al. 2003). At the sites with bird droppings, we measured significantly lower foliar K concentrations, and significantly higher $\mathrm{N}: \mathrm{K}$ and $\mathrm{P}: \mathrm{K}$ ratios, indicating that $\mathrm{K}$ could be co-limiting growth (Table 5). We must consider, however, that strongly increased growth paired with decreasing nutrient concentrations can indicate a considerable increase in nutrient uptake, although at a lower rate than the rate of biomass accumulation. Tissue nutrient concentrations are therefore not the best measure of the effect of bird droppings because the bird droppings had a strong effect on the biomass (measured as length of the longest leaves) of $N$. ossifragum.

Pine bogs with Sphagnum dominance in the bottom layer are widespread, although not in Ireland. Sharavogue bog, however, features small groups of Pinus sylvestris trees. The larger trees had several Hooded crow nests and the understorey indicated more eutrophic growth conditions. Tissue nutrient concentrations in the Sphagnum growing underneath the Pinus trees were higher than those at the reference sites (Table 4). All the smaller trees appeared to have become established in the same year, although their height differed significantly (Fig. 2). Abiotic conditions were obviously more suitable for tree growth closer to the "mother" tree. Although factors such as light and moisture could have affected growth along the transect, these factors were probably of less importance than the increased nutrient availability resulting from bird droppings. A 40-year study in southcentral Sweden revealed that vascular plant species, including tree species, increased in frequency probably as a result of increased availability of $\mathrm{N}$ and drier conditions (Gunnarsson et al. 2002). 
On Clara bog, the trees that had been planted in the immediate vicinity of the survey posts were also able to grow rapidly and appeared very vigorous (Fig. $3 b$ ). In contrast, the small Pinus trees that we planted at the reference sites had very poor growth and yellowish needles (Fig. $3 a$ and Table 6). Recent measurements of the height of the Pinus trees, 4 years after transplantation, show that the difference in growth rates of Pinus at reference sites and in the vicinity of survey posts has become even more pronounced (Fig. 4). Comparing the tissue nutrient concentrations of the current year's needles with the threshold values of nutrient concentrations for nutrient deficiency in Pinus sylvestris as given by Houdijk and Roelofs (1993), the P and K concentrations were too low for optimal growth at the reference sites. Around the wooden posts only $\mathrm{K}$ seemed suboptimal for growth. Growth of Pinus sylvestris on Clara bog was limited by both $\mathrm{P}$ and $\mathrm{K}$, whereas growth at the sites with bird droppings was only limited by $\mathrm{K}$, owing to the huge input of $\mathrm{P}$ from bird droppings. Finér (1992) also found that the growth of trees on bogs is often limited by $\mathrm{P}$ and $\mathrm{K}$, as PK and NPK fertilization increased, the growth of Pinus sylvestris growing on an ombrotrophic pine bog. Once established, an increased tree cover can have radical effects on the bog ecosystem (Frankl and Smeidl 2000; Ohlson et al. 2001). Pinus sylvestris, for instance, is capable of creating and maintaining a fundamentally different environment in bogs, and inevitably brings an end to Sphagnum dominance by altering local hydrological conditions and increasing the accumulation of litter (Frankl and Smeidl 2000; Ohlson et al. 2001).

\section{Effect of bird droppings on ombrotrophic bogs}

Based on our results, we conclude that non-characteristic herbs and trees are only able to grow on ombrotrophic bogs if nutrient availability, especially that of $\mathrm{P}$ and $\mathrm{K}$, is sufficiently high. Sites on bogs characterized by increased nutrient availability include the so-called flushes or soak systems (Kelly 1993), but also sites eutrophicated by the presence of birds. Avian communities of typical open raised bogs are generally poor in species. Increased structural complexity of the vegetation, particularly in terms of the vertical component, increases the plant density, and thus, increases foraging and nesting opportunities for birds (Bölscher 1995). On Clara bog, the plants that most notably affected the increase in structural complexity were Molinia caerulea, Myrica gale, J. effusus, R. fruticosus, B. pubescens, and Pinus sylvestris, but the wooden survey posts were also proven to attract birds. The major increase in nutrient availability from bird droppings allowed these plant species in particular to grow on the bogs. This increase in vegetation structure provides birds with foraging and nesting opportunities, which leads to greater densities of birds and a further increase in nutrient availability (Fig. 5). We assume that this is a selfenhancing process that may even result in small patches of bog forest in the long term.

In addition, the increased structure of the vegetation results in more efficient filtering of dry atmospheric deposition, and thus increases the total nutrient deposition rate (e.g., Ivens 1990). Increased canopy density can also intercept larger amounts of rainfall and reduce the amount of water reaching the peat surface (Tomassen 2004). Since most
Irish bogs suffer from the effects of water table draw-down as a result of small-scale peat extraction and the presence of drainage ditches, reduced water input from precipitation may enhance the water shortage for ombrotrophic vegetation. In Sphagnum suffering from water stress, gas exchange is suppressed, resulting in reduced photosynthetic rates and growth (Hayward and Clymo 1983; Schipperges and Rydin 1998), reduced immobilization of nutrients by the Sphagnum layer (Aldous 2002), and increased availability of nutrients for vascular plants. All these processes will ultimately stimulate the growth of atypical grasses and trees and are disastrous for characteristic ombrotrophic species. Cascading effect of nutrient subsidies have also been found for tundra ecosystems, where faeces of reindeer promoted grasses while suppressing mosses (Van der Wal et al. 2004).

We conclude that once a tree has become established on a bog, it can have significant effects on the vegetation composition in its direct vicinity because of bird droppings. Bird droppings may have a large impact on the vegetation composition, organic matter decomposition, and structure of ombrotrophic bogs, which may even result in the development of small patches of bog forest. For treeless bogs, such as Clara bog, these small patches of bog forest will largely affect the typical open landscape.

\section{Acknowledgements}

We thank Jelle Eygensteyn, Liesbeth Pierson, Annemarie Teunissen, and Rick Kuiperij for their help with the chemical analyses; Juul Limpens, Esther Lucassen, Marcel Isken, Roy Peters, and Jeanine Berk for field assistance; Dúchas the Heritage Service for permission to conduct experiments at Clara bog and Raheenmore bog; Gert-Jan van Duinen and R.S. Clymo for comments on the manuscript; and Jan Klerkx for linguistic advice.

\section{References}

Aaby, B. 1994. Monitoring Danish raised bogs. In Mires and man. Mire conservation in a densely populated country - the Swiss experience. Edited by A. Grünig. Swiss Federal Institute for Forest, Snow \& Landscape Research, Birmensdorf, Switzerland. pp. 284-300.

Aerts, R., Wallén, B., and Malmer, N. 1992. Growth-limiting nutrients in Sphagnum-dominated bogs subject to low and high atmospheric nitrogen supply. J. Ecol. 80: 131-140.

Aldous, A.R. 2002. Nitrogen retention by Sphagnum mosses: responses to atmospheric nitrogen deposition and drought. Can. J. Bot. 80: 721-731.

Barkman, J.J. 1992. Plant communities and synecology of bogs and heath pools in the Netherlands. In Fens and bogs in the Netherlands: Vegetation, history, nutrient dynamics and conservation. Edited by J.T.A. Verhoeven. Kluwer Academic Publishers, Dordrecht, the Netherlands. pp. 173-235.

Berendse, F., Van Breemen, N., Rydin, H., Buttler, A., Heijmans, M., Hoosbeek, M.R., Lee, J.A., Mitchell, E., Saarinen, T., Vasander, H., and Wallén, B. 2001. Raised atmospheric $\mathrm{CO}_{2}$ levels and increased $\mathrm{N}$ deposition cause shift in plant species composition and production in Sphagnum bogs. Global Change Biol. 7: 591-598.

Bobbink, R., and Lamers, L.P.M. 2002. Effect of increased nitrogen deposition. In Air pollution and plant life. 2nd ed. Edited by 
J.N.B. Bell and M. Treshow. John Wiley \& Sons Ltd., New York. pp. 201-235.

Bobbink, R., and Roelofs, J.G.M. 1995. Nitrogen critical loads for natural and semi-natural ecosystems: the empirical approach. Water Air Soil Pollut. 85: 2413-2418.

Bobbink, R., Hornung, M., and Roelofs, J.G.M. 1998. The effects of air-borne nitrogen pollutants on species diversity in natural and semi-natural European vegetation. J. Ecol. 86: 717-738.

Bölscher, B. 1995. Niche requirements of birds in raised bogs: habitat attributes in relation to bog restoration. In Restoration of temperate wetlands. Edited by B.D. Wheeler, S.C. Shaw, W.J. Fojt, and A. Robertson. John Wiley \& Sons Ltd., Chichester, UK. pp. 359-378.

Cocks, M.P., Balfour, D.A., and Stock, W.D. 1998. On the uptake of ornithogenic products by plants on the inland mountains of Dronning Maud Land, Antarctica, using stable isotopes. Polar Biol. 20: 107-111.

Cocks, M.P., Harris, J.M., Steele, W.K., and Balfour, D.A. 1999. The influence of ornithogenic products on the nutrient status of soils surrounding nests on nunataks in Dronning Maud Land, Antarctica. Polar Res. 18: 19-26.

Cross, J.R. 1987. Unusual stands of Birch on bogs. Ir. Nat. J. 22: 305-310.

Fariña, J.M., Salazar, S., Wallem, K.P., Witman, J.D., and Ellis, J.C. 2003. Nutrient exchanges between marine and terrestrial ecosystems: the case of the Galapagos sea lion Zalophus wollebaecki. J. Anim. Ecol. 72: 873-887.

Finér, L. 1992. Nutrient concentrations in Pinus sylvestris growing on an ombrotrophic pine bog, and the effects of PK and NPK fertilization. Scand. J. For. Res. 7: 205-218.

Frankl, R., and Schmeidl, H. 2000. Vegetation change in a South German raised bog: Ecosystem engineering by plant species, vegetation switch or ecosystem level feedback mechanisms. Flora, 195: 267-276.

Gould, D.J., and Fletcher, M.R. 1978. Gull droppings and their effect on water quality. Water Res. 12: 665-672.

Grasshoff, K., and Johannsen, H. 1977. A new sensitive method for the determination of ammonia in sea water. Water Res. 2: 516.

Gunnarsson, U., Malmer, N., and Rydin, H. 2002. Dynamics or constancy in Sphagnum dominated mire ecosystems? A 40-year study. Ecography, 25: 685-704.

Hayward, P.M., and Clymo, R.S. 1983. The growth of Sphagnum: experiments on, and simulation of, some effect of light flux and water-table depth. J. Ecol. 71: 845-863.

Heijmans, M.M.P.D., Berendse, F., Arp, W.J., Masselink, A.K., Klees, H., De Visser, W., and Van Breemen, N. 2001. Effects of elevated carbon dioxide and increased nitrogen deposition on bog vegetation in the Netherlands. J. Ecol. 89: 268-279.

Hogg, P., Squires, P., and Fitter, A.H. 1995. Acidification, nitrogen deposition and rapid vegetational change in a small valley mire in Yorkshire. Biol. Conserv. 71: 143-153.

Hoosbeek, M.R., Van Breemen, N., Vasander, H., Buttler, A., and Berendse, F. 2002. Potassium limits potential growth of bog vegetation under elevated atmospheric $\mathrm{CO}_{2}$ and $\mathrm{N}$ deposition. Global Change Biol. 8: 1130-1138.

Houdijk, A.L.F.M., and Roelofs, J.G.M. 1993. The effects of atmospheric nitrogen deposition and soil chemistry on the nutritional status of Pseudotsuga menziesii, Pinus nigra and Pinus sylvestris. Environ. Pollut. 80: 79-84.

Ivens, W. 1990. Atmospheric deposition onto forests: an analysis of the deposition variability by means of throughfall measurements. Ph.D. thesis, University of Utrecht, the Netherlands.

Jauhiainen, J., Wallén, B., and Malmer, N. 1998. Potential $\mathrm{NH}_{4}{ }^{+}$ and $\mathrm{NO}_{3}{ }^{-}$uptake in seven Sphagnum species. New Phytol. 138: 287-293.

Jordan, C. 1997. Mapping of rainfall chemistry in Ireland 1972-94. Biol. Environ. 97B: 53-73.

Kelly, M.L. 1993. Hydrology, hydrochemistry and vegetation of two raised bogs in county Offaly. Ph.D. thesis, Trinity College, Dublin, Ireland.

Koerselman, W., and Meuleman, A.F.M. 1996. The vegetation N:P ratio: a new tool to detect the nature of nutrient limitation. J. Appl. Ecol. 33: 1441-1450.

Lamers, L.P.M., Bobbink, R., and Roelofs, J.G.M. 2000. Natural nitrogen filter fails in polluted raised bogs. Global Change Biol. 6: $583-586$.

Lee, J.A., and Woodin, S.J. 1988. Vegetation structure and the interception of acidic deposition by ombrotrophic mires. In Vegetation structure in relation to carbon and nutrient economy. Edited by J.T.A. Verhoeven, G.W. Heil, and M.J.A. Werger. SPB Academic Publishers, The Hague, the Netherlands. pp. 137-147.

Leentvaar, P. 1967. Observations in guanotrophic environments. Hydrobiologia, 39: 441-489.

Limpens, J., Berendse, F., and Klees, H. 2003. N deposition affects $\mathrm{N}$ availability in interstitial water, growth of Sphagnum and invasion of vascular plants in bog vegetation. New Phytol. 157: 339-347.

Limpens, J., Berendse, F., and Klees, H. 2004. How P availability affects the impact of $\mathrm{N}$ deposition on Sphagnum and vascular plants in bogs. Ecosystems, 7: 793-804.

Lindeboom, H.J. 1979. Chemical and microbiological aspects of the nitrogen cycle on Marion Island (sub-Antarctic). Ph.D. thesis, University of Groningen, Groningen, the Netherlands.

Maksimova, T.A., and Yudina, V.F. 1999. The effect of small doses of mineral fertilizers on the vegetation of a Sedge-Sphagnum bog. Russ. J. Ecol. 30: 382-386.

Malmer, N. 1993. Mineral nutrients in vegetation and surface layers of Sphagnum-dominated peat-forming systems. Adv. Bryol. 5: 223-248.

Malmer, N., Svensson, B.M., and Wallén, B. 1994. Interactions between Sphagnum mosses and field layer vascular plants in the development of peat-forming systems. Folia Geobot. Phytotaxon. 29: 483-496.

Malmer, N., Albinsson, C., Svensson, B.M., and Wallén, B. 2003. Interferences between Sphagnum and vascular plants: effects on plant community structure and peat formation. Oikos, 100: 469482.

Mills, G. 2000. Modelling the water budget of Ireland - evapotranspiration and soil moisture. Ir. Geogr. 33: 99-116.

Ohlson, M., Økland, R.H., Nordbakken, J-F., and Dahlberg, B. 2001. Fatal interactions between Scots pine and Sphagnum mosses in bog ecosystems. Oikos, 94: 425-432.

Paffen, B.G.P. 1990. Possibilities for regeneration of raised bog vegetation in 'De Groote Peel'. Department of Aquatic Ecology and Biogeology, University of Nijmegen, Nijmegen, the Netherlands. [In Dutch.]

Risager, M. 1998. Impacts of nitrogen on Sphagnum dominated bogs with emphasis on critical load assessment. Ph.D. thesis, University of Copenhagen, Copenhagen, Denmark.

Schipperges, B., and Rydin, H. 1998. Response of photosynthesis of Sphagnum species from contrasting microhabitats to tissue water content and repeated desiccation. New Phytol. 140: 677684.

Smolders, A.J.P., Tomassen, H.B.M., Lamers, L.P.M., Lomans, B.P., and Roelofs J.G.M. 2002. Peat bog restoration by floating raft formation: the effects of ground water and peat quality. J. Appl. Ecol. 39: 391-401. 
Summerfield, R.J., and Rieley, J.O. 1975. Relationships between mineral supply and growth of Narthecium ossifragum (L.) Huds. on mire ecosystems. J. Ecol. 63: 643-656.

Swift, M.J., Heal, O.W., and Anderson, J.M. 1979. Decomposition in terrestrial ecosystems. University of California Press, Berkeley, Calif.

Technicon. 1969. Industrial method 33-69W, nitrate + nitrite in water. In Technicon AutoAnalyser methodology. Technicon Corporation, Karrytown, N.Y. pp. 1-2.

Tomassen, H.B.M. 2004. Revival of Dutch Sphagnum bogs: a reasonable perspective? Ph.D. thesis, Radboud University Nijmegen, Nijmegen, the Netherlands.

Tomassen, H.B.M., Smolders, A.J.P., Lamers, L.P.M., and Roelofs, J.G.M. 2003. Stimulated growth of Betula pubescens and Molinia caerulea on ombrotrophic bogs: role of high levels of atmospheric nitrogen deposition. J. Ecol. 91: 357-370.

Tomassen, H.B.M., Smolders, A.J.P., Limpens, J., Lamers, L.P.M., and Roelofs, J.G.M. 2004. Expansion of invasive species on ombrotrophic bogs: desiccation or high $\mathrm{N}$ deposition levels? J. Appl. Ecol. 41: 139-150.

Updegraff, K., Pastor, J., Bridgham, S.D., and Johnston, C.A. 1995. Environmental and substrate controls over carbon and nitrogen mineralization in northern wetlands. Ecol. Appl. 5: 151-163.

Van der Schaaf, S. 1999. Analysis of the hydrology of raised bogs in the Irish Midlands. A case study of Raheenmore bog and Clara bog. Ph.D. thesis, Wageningen University, Wageningen, the Netherlands.

Van der Wal, Bardgett, R.D., Harrison, K.A., and Stien, A. 2004. Vertebrate herbivores and ecosystem control: cascading effects of faeces on tundra ecosystems. Ecography, 27: 242-252.

Warren, W.P., Smyth, M., Van der Meer, J.J.M., and Hammond, R.F. 2002. Geology. In Conservation and restoration of raised bogs, geological, hydrological and ecological studies. Edited by M.G.C. Schouten. Department of the Environment and Local Government, Dublin, and Staatsbosbeheer, the Netherlands. pp. $16-31$. 